\title{
Creating Dangerously
}

Eric DeMeulenaere

\begin{abstract}
Universities and scholars have long wrestled with the types of impact they want their work to have on the world. This narrative explores the challenge of impact from the perspective of a recently tenured professor reflecting on his case for tenure and his struggle to fit his activist scholarship within the genre of the tenure case, which requires candidates to explain their work and its impact. Through an examination of this struggle, the author identifies three challenges that universities need to confront if they want to enable more community-engaged scholarship: 1) The problem of expertise, 2) the problem of genre, and 3) the problem of focus. If and when the academy begins to address these challenges, the author argues, activist scholars will no longer have to hide the nature of their community engaged work and their scholarship will be able to better reach larger audiences beyond the academy.
\end{abstract}

Keywords: activism, engaged scholarship, tenure, community-engagement, academia

[Excerpt One] I locked up the school building as I walked out with some of the teachers. We had just completed four hours of our final evening of student portfolio exhibitions. Tomorrow we were taking all our students to a water park to celebrate the completion of our first year as a new high school for social justice in Oakland.

It had been both an exhausting and gratifying day. Students showcased their yearlong learning in front of families, teachers and fellow students in their advisory classrooms. I enjoyed seeing the students' nerves on display and the beaming smiles of parents.

One of the parents smiling was Karen Robinson. I had come to know her through several conflicts involving her son, DeShawn, throughout the year. We had worked well together through these challenges, and I had grown to really respect her and DeShawn. DeShawn's strong "street" sensibilities did not prevent him from earning all A's and B's in part because of her discipline and DeShawn's effort and intelligence. I shared a smile with her Monday night as DeShawn presented his research on Buddhism and connected the insights of what he had learned to his own life. It was a triumphant conclusion to our first year.

DeShawn's mother drove home allowing DeShawn to hang out with his friends from the neighborhood. Some conflict ensued with another youth. Later that evening, DeShawn caught the bus heading home. Unbeknownst to him, the youth involved in the earlier conflict had followed him home to address his earlier 
humiliation. As DeShawn placed his key into the gate of his apartment complex, the shot rang out. A bullet ripped through DeShawn's neck. Somehow, he managed to crawl up the steps to his second floor apartment where he collapsed and bled to death in his mother's arms. ... .

My scholarship is born from pain. I, in the words of bell hooks (1994), "came to theory because I was hurting.... I came to theory desperate, wanting to comprehend - to grasp what was happening around and within me. Most importantly, I wanted to make the hurt go away" (p. 59).

[Excerpt Two] My scholarship is born from rage - rage against a world that allows DeShawns to be murdered. DeShawn is not the only student I have buried. I have worked with so many other youth who, though physically alive, have had their dreams and hopes dashed in a myriad of ways.

I never sought to be a scholar. Even after earning my Ph.D. in Education in 2003, I worked to open a school for social justice. I wanted to be involved in the creation of radical social change. However, the deeper I entered into such activist work, the more I was compelled to theorize and explore the complexities and contradictions of this work. The reality of urban America pushed me to research, theorize and write. I could not remain silent. In the words of Albert Camus (1961), "Today, everything is changed and even silence has dangerous implications.... To create today is to create dangerously. Any publication is an act, and that act exposes one to the passions of an age that forgives nothing." As it was for Camus, this current social reality compels me to create dangerously.

In her book Create Dangerously, Edwidge Danticat (2011) writes "[authors possess] the desire to interpret and possibly remake his or her own world. So though we may not be creating as dangerously as our forebears - though we are not risking torture, beatings, executions, though exile does not threaten us into perpetual silence- - still while we are at work bodies are littering the streets somewhere" (p. 18). When I look at the state of education in this country, when I think of Deshawn, or Trayvon Martin, or Mike Brown, I can see that these are indeed dangerous times. As a scholar, therefore, I seek to create dangerously.

To create dangerously, my work must not only examine and ponder the realities of urban violence, poverty and racial oppression, but also seek to address these realities. These realities pose many questions: Why do our urban youth live lives filled with so much violence, poverty and racial oppression? How do these social toxins shape young people's development? Why do schools fail to confront and address these social realities? In addition to examining the existing realities, my work must also explore what could be. How can we change schools to confront these realities? What does effective teaching and youth development look like in urban communities? 
These are dangerous questions. They are not simply intellectual pursuits. These questions also lead to other dangerous questions. Who am I to think I can address these questions? How does my own social location shape my ability to consider and address such social realities? What does it mean to engage in such scholarship from a place of privilege as a white male, middle-class academic?

Antonio Gramsci argues that most public intellectuals view themselves as distinct from the structures that create and maintain social inequities, but are instead complicit. Gramsci called for the rise of new counter-hegemonic intellectuals who work to transform the ideological and material conditions that maintain inequity. These new counter-hegemonic intellectuals, Gramsci asserted, "can no longer consist in eloquence ... but in active participation in practical life, as constructor, organizer, 'permanent persuader' and not just a simple orator" (Gramsci, 1971, p. 10). These new transformative intellectuals cannot simply offer revolutionary ideas removed from concrete participation in the lives of the people they seek to liberate.

This was the final version of how I began my research statement for tenure. One of my academic mentors reviewed my initial draft, which had an even longer opening story, and cautioned me against opening my statement this way. While she appreciated the words and intention of this opening, she was concerned that I had used over half of my three-page limit to tell stories and I had not yet mentioned my research. Further, she had read many tenure cases and she had concerns that reviewers might not respond well to this divergence from the norm. I eventually cut the introduction down to the version above, but I decided I needed to keep the introduction, long as it was, mostly intact.

Perhaps this was a silly risk for a document intended for a small audience of reviewers. However, I had just recently read Edwidge Danticat's (2011) book, Create Dangerously, and I was deeply enraged by the numerous deaths of black youth at the hands of police and vigilantes and the Movement for Black Lives inspired me further. It was a time to take risks, I felt. I wanted to situate my work as a scholar within the pain and rage that fueled it.

I had also just spent time trying to quantify the impact of my own academic writings based on citations and journal impact factors. However, this quantification felt inadequate to me. Did it really reflect the true impact of my work? The first academic article I published featured two young brilliant and creative former students of mine who I followed from middle school into the first couple of years of high school in San Francisco. They taught me so much about the creative identity performances African-American youth had to play to achieve success in troubled city schools. Yet one of these students, Mike, would be shot and killed before he graduated high school. How do I talk about the impact of my work, in terms of how many other members in the academy have read or cited it, when no knowledge I had developed through countless hours of work with Mike had made an impact on preventing Mike's violent death? I wanted my work to matter in the lives of students like Deshawn and Mike, and indexing the articles I had written and their reception by academics seemed remarkably inadequate by contrast. Therefore, while I wanted to achieve tenure, it seemed minor compared to what was happening around me. I felt an 
urgency to give voice to that in my tenure case. Taking risks, especially such a small one as gaining tenure, therefore felt important.

More urgently, I wanted to be more engaged in work that mattered in the realities of the youth and families with whom I worked. Gramsci's words haunted me. Was I, like so many of the public intellectuals that Gramsci identified, fooling myself into thinking I was engaged in the "active participation in practical life" in the communities where I worked? Did I, all the while, remain a "simple orator" professing in classrooms and publishing in obscure journals read only by other academics? How could I think about, write about and engage in scholarship that mattered in the lives of the youth and families with whom I had the privilege to work and learn?

Of course, it was not lost on me that Edwidge Danticat and Albert Camus became more widely known and read for their fiction rather than their more academic non-fiction. What could I do to construct knowledge that did not simply get recorded in academic journals and pad my own curriculum vitae, but instead became knowledge that mattered in the lives of the youth with whom I worked? At the time, I had created a non-profit with community artists called N-CITE Community Media that engaged Worcester youth in critical media literacy and developed them as counter-hegemonic film-makers and storytellers. We taught them to critically read the ways that they were misrepresented in the media and then gave them the skills to develop documentary films that offered counter-narratives to, as our motto stated, "disrupt the dominant narrative." At N-CITE Community Media, we took cohorts of youth to develop films from concept through post-production. N-CITE youth wrote, directed, produced and edited documentary films. Our youth produced films based on their own life stories. They made films that addressed issues like youth immigration, colorism, youth homelessness, refugee youth and body image. We hosted multiple screenings at conferences and film-festivals and in schools and churches. Our youth presented their films and talked with thousands of audience members. For instance, for our film on youth immigration, we presented to not only general audiences, but we also held special screenings with local and federal politicians, including a screening at the Massachusetts' state house hosted by the state senate president.

The process of developing and presenting these films had various impacts on the youth involved. We watched some of the youth completely transform their life trajectories. Indeed, I am currently concluding a youth participatory action research (YPAR) project with a few of the youth graduates from the program in which we document the impact the N-CITE program had on the youth. Yet what was the impact on the audience members? That is more difficult. Just as I can count downloads or citations on my articles, I cannot address how people read my writings and how the articles affected them. Similarly, while I can count the number of people in the room for a screening, it is difficult to assess the impact the film screening had on audience members. Nevertheless, I do know that the people who watched these screenings included youth, college students, church members, politicians and other community members who are much less likely to read an academic article on the subject. Therefore, I know, at least, that the films are reaching folks beyond the academy.

The commitments I make to my work as a community educator and organizer and activist for social change at times comports wonderfully with my work as an academic, but often there are conflicts and challenges to my activist commitments and my work as an academic. In a 
forthcoming book, The Activist Academic, my co-author and I trace our journey towards tenure as we try to reconcile the challenge of merging our work as activists with that of being new academics. Below, as a recently tenured associate professor, I briefly explore three of these challenges: (a) The problem of expertise; (b) the problem of genre; and; (c) the problem of focus.

\section{The Problem of Expertise}

My writing about my work in the previous two paragraphs reads in the first person singular. Yet when I am writing about my work in N-CITE Community Media and the films we have produced, I cannot really say "I" anymore or call it "my" work. Certainly, I am coordinating and facilitating a program that brings in youth to learn how to make films and to tell their own stories. I organize and help to teach in the program. I provide feedback and guidance along the way. I help to edit and make suggestions throughout the process. Nevertheless, I have co-run the program with a powerful community filmmaker and youth worker. Even more importantly, the youth conceive and pitch the ideas for these films. The youth go through a collective process to select the film topics. Moreover, the youth share their stories. In addition, the youth film, direct and manage the sound on all the shoots. They write the questions and conduct the interviews. Finally, the youth do most of the editing as we collaboratively stitch the film together. I help facilitate the entire process. I certainly deserve the production credits I have for each film. Nevertheless, how does this appear on my curriculum vitae and how will (or should it) count towards the assessment of my scholarship in terms of promotion? How much of this should count as "my" work?

In the youth participatory action research investigation that I am completing with a team of five youth, we have produced both a film about N-CITE and are finalizing an academic article. As part of the interviews that we conducted, the youth suggested, and I consented, that the interviews would flow better if I were not present at the interviews with the other youth. These youth interviews are the bulk of the data we collected and the footage we shot. While I initiated this project, the decisions we made were taken collectively, and the youth did the majority of the work, including library research and developing and writing the conceptual frameworks, the findings, and much more. This raises questions about authorship. Who is the lead author? Who holds the authority and expertise? How do colleges value my contributions to projects like this? How should they?

This is even more complicated when thinking about the valuing of my contribution towards youth-created documentary films. Whose expertise comes to shine? I am not an expert on colorism or youth immigration. Indeed, we sought out experts to help us understand these ideas in creating the films. I learned a ton in the process. Yet I only learned so much by following the lead of the youth in our program. In the academy I earn my salary for being able to "profess" about my areas of expertise, so what does this mean for my identity as an academic to be developing work that regularly positions me as a student outside my "area of expertise?" How do I represent myself in this collective knowledge construction? On one level, I can position myself as an expert on the process: the pedagogy of creating these collaborative working teams that tell counter-stories through film. Does that mean that I only earn credit with what I write about the process? What about the films and writings that the youth teams produce? Engaged scholarship 
led by members in the community creates challenges about our notions of expertise that remain fundamental to the way academics are constructed.

\section{The Problem of Genre}

The problem of authorship or producer/director-ship is, of course, only the first of the challenges. The second, as is clear when you are working with film as an academic, is the problem of genre. In the academy, particularly in the social sciences more broadly, the types of produced works that are most privileged are journal articles and books. Thus, there is a huge question of what can count as knowledge products for advancing our academic careers. A documentary film might reach broader and more diverse audiences; should it count as part of my academic research portfolio? Until recently, I assumed my youth filmmaking was a separate area of work that did not go on my curriculum vitae, or if it did, it was part of my community service, not my scholarship. However, a couple of years ago I presented some clips from a film I helped to produce at a conference. In the conversation that occurred after my talk, Dr. John Saltmarsh argued that the films deserve recognition as a part of my scholarship. Since then, I have added them to my curriculum vitae, but I wonder how committees reviewing my work perceive them. Should I have included a film DVD as part of my portfolio for tenure?

The problem of genre exists even when we are not talking about different media like film and radio. It occurs in other writing projects as well. In many community-centered projects, activists who are also academics are members of teams who complete writing tasks as part of community organizing projects. For instance, I wrote several grant proposals for N-CITE Community Media. I also did the writing to secure the non-profit status. More recently, I have worked with a team of community educators, artists and parents to develop an innovative proposal for a new secondary school in Worcester. I was heavily involved in writing the school proposal and its business plan. Should these writings remain in the domain of service? Do they ever cross over into scholarship? How do we begin to answer these types of question related to genre?

Furthermore, even within writing for more academic audiences, the question of genre arises not only in the mediums through which we communicate, but also through the style of writing. In my own efforts to avoid using "the masters' tools" (Lorde, 1984, p. 112) I have striven to write in an accessible language that situates my own subjectivity within my words. This means I rely heavily on narrative, including my own personal narratives. However, university faculty too often deride the use of personal narrative as lacking intellectual rigor or not being academic. In my first book, my co-author and I got through the reviewers by writing every other chapter as a narrative followed by chapters that were more traditional academic writings that provided a critical analysis of the more narrative (and engaging) chapters. Indeed, in our introductory guide to how to read the book, we offer a secret: readers can concentrate on the narrative chapters alone, and learn quite a lot.

In our follow-up collaboration, we developed a form of writing that we came to call critical coconstructed auto-ethnography. The book conceptualizes, in a new way, the meaning of research, teaching, and service for activist academics, along with chapters that are devoted to critical theory, academic collaboration and mentoring. Rather than present these ideas in a traditional academic writing, the book is a narrative written in seven chapters with each chapter 
representing a year in our lives as we entered the academy and moved towards earning tenure. The narrative captures conversations between us in cafes, living rooms, at conferences and over Skype. We seek to not only address intellectual ideas, but also capture the pace of life as academics with families: our family members become secondary characters in the narrative of the text. We wanted to capture together the intellectual ideas we wrestle with as academics, but to do so within the realistic pace of our lives amidst the regular struggle to marry our new academic selves with our activist commitments and the challenge to maintain our obligations to our families, our students and our universities. Additionally, we wanted to make the book even more humanizing and capture the conflicts, the teasing, the humor and the love that is also a part of our relationship.

We actually began writing this book not long after we both moved our families across the country and entered academia. It was initially a cathartic form of writing. That is, it helped us process and reflect on all of the struggles we had encountered, as we became academics. Slowly, the writing evolved into a passion project for us as we began to consider turning it into a book. Then we struggled to find a publisher willing to embrace it. On the one hand, it seemed to be too broad in scope, with too much personal narrative, to appeal to academic presses. On the other, it was too broad and academic for mainstream presses who publish books by Malcolm Gladwell, Paul Tough and the like. Furthermore, the co-authorship and intellectual ideas pushed it outside the memoir genre. We still do not really know how to define its genre. After over four years of trying to get it published, we were about to just give up on it, but fortunately another press forwarded our proposal to a new publisher who is willing to take a risk on us.

This struggle speaks to the problem of genre that we face in the academy. Now that we are going to get it published, we will get to see how the book will be reviewed by academics and how, and even if, it will be considered as part of our portfolio of work as we seek future promotions. There are clear boundaries on the types of knowledge that are valued in the academy. This is not only a challenge for when we venture outside writing and into more accessible formats like films or podcasts, it also includes problems of genre and style within the written word.

\section{The Problem of Focus}

Diversifying expertise and genre relate to the more general problem of focus. When I wrote my statement for tenure, my advisors told me that I needed to capture my scholarship into a single area or maybe two areas of focus. Attempting to unify my diverse writings into a single area of work, I wrote:

As a scholar of urban schooling, my research has focused on culture change in and out of schools to transform the social and material realities affecting urban youth. My research, grounded in sociology and cultural studies, examines the social and cultural dynamics that enable or prevent learning, reform, and youth development to take hold (DeMeulenaere, Research Statement).

Re-reading the statement again, I am struck by how in attempting to try to fit my work into a singular focus, I offered a very broad and vague statement to create unification. This was even before I tried to include films about immigration and colorism into "my 
scholarship." The challenge of focus faces every engaged scholar who really values the voice and expertise of the community members with whom they work. My own partnerships in the last decade have included working with schools leaders to enact school wide change. Our collaborations include: (a) running critical inquiry groups with school teachers; (b) co-teaching critical pedagogies in a public high school; (c) coordinating an anti-racist youth organization; (d) organizing parent coalitions; (e) developing and teaching in a critical media literacy and youth film production program; and (f) working with parents, educators and artists to develop a new school for arts-based social justice.

Aside from the critical inquiry group for teachers, I neither initiated nor led any of these projects. I helped to facilitate them and learned a ton from my involvement in them. Indeed, my learning became the basis for much of my scholarship. However, throughout, I was following the lead of others rooted in the community members who expressed a need to create change, often at very different levels and very diverse sites. I have worked in elementary schools, in high schools and in out-of-school programs. I have collaborated with school leadership and schoolteachers and worked directly with youth as a teacher, youth worker, and mentor. I have worked at grassroots organizing, whole school change, social policy change, and state and federal reforms. I have worked to shift material realities as well as focusing on shifting the ideological roots that construct and maintain social inequality. This diversity of engagements is held together only by a commitment to critical engagement with social problems and the development of trusting relationships with community members. My relationships with different people (teachers, youth, school leaders, community artists), who identify different community problems to tackle, have led me down very diverse paths.

These shifts of focus are not valued in the academy. We are supposed to have a long career with a singular focus. However, to maintain this focus implies that academics always set the agenda for their research. They are the leaders determining the participants and the research questions. If they team up, they team up with other academics in their same field. One of the questions I often get when I present at conferences is how I came to develop my interest in social justice. No one asks this in the question and answer period, but by young scholars who come up afterwards to talk. This question is always puzzling to me. The question implies that working for social justice is like choosing your field of research. However, I do not usually call or refer to my work as social justice work, as if that is a field or a category. The work I do grows out of developing trusting and caring relationships with people, which inherently involves sharing their pain and struggles. When the people you care about are hurting and there is a way we can do something about it, you just act. I usually figure out how to make it into research secondarily, after I have learned something. In addition, sometimes, to the detriment of my academic career, I recognized that the story is not meant to be shared (Tuck \& Yang, 2014).

Activist academics committed to engaging with and following the lead of the community cannot dictate that the focus of their work address their needs within the academy and be situated within their areas of focus. To capture that reality, I included a brilliant quote by 
Carter G. Woodson in an early draft of my research statement, which I regrettably removed in favor of my attempts to make my work seem more focused. Here is how I framed it in that early draft:

My scholarship and work, then, in the eloquent words of Carter G. Woodson, situates me as a servant of the people engaging in transformative work:

You cannot serve people by giving them orders as to what to do. The real servant of the people must live among them, think with them, feel for them, and die for them... The servant of the people, unlike the leader, is not on a high horse trying to carry the people to some designated point to which he would like to go for his own advantage. The servant of the people is down among them, living as they live, doing what they do and enjoying what they enjoy. He may be a little better informed than some of the other members of the group; it may be that he has had some experience that they have not had, but in spite of this advantage he should have more humility than those whom he serves" (Woodson, 1933, p. 131)

Thus, I strive to be this new counter-hegemonic intellectual, a servant of the people. While I removed this from final my research statement for tenure, I wish I had not. Indeed, I wish I felt I could have presented myself with greater humility. While I strive to listen and follow the guidance and expertise of the community members with whom I a privileged to work, in my statement for tenure I instead tried to present myself as a community leader. I also strove to construct a narrative that would unify the diverse projects I worked on into a single focused narrative.

Challenging this need to center ourselves in our community-engaged scholarship, some of my community-engaged colleagues and I have worked to create a new major on campus centered on community-engaged scholarship for students. In this new major, Community, Youth, and Education Studies (CYES), students advance through a threecourse sequence to develop their own praxis-projects in community spaces in which they are situated. Despite our push to have students listen to their community partners and develop change projects in deep collaboration and consultation with community partners, we have to repeatedly remind them to listen and learn rather than try to lead their communities "to some designated point to which [they] would like to go for [their] own advantage." While engaging our students in community-engaged praxis projects, we also sought to create this interdisciplinary major to be a space for faculty committed to activist scholarship to build, support, and improve our own efforts as community-engaged scholars. Stepping into leadership in this space has been both humbling and rewarding as we continue to "make the road by walking" (Horton \& Freire, 1990).

I opened this piece claiming that my insertion of a narrative at the beginning of my research statement for tenure was an effort to take a risk. Perhaps the real risk would have been to admit that I am follower more than a leader, a listener more than an orator, and a student more than I am a teacher. Maybe that is just the reality all of us face who try merge our community-based activist selves with our academic identities. Perhaps we have to speak differently depending on the audience and the expectations there. Yet I wonder what it might be like if I did not have to hide my activist identity within the 
academy, and I could be fully transparent as both an academic and activist, whether I am at an organizing meeting in a church or preparing my case for tenure. 


\section{References}

Camus, A. (1961). Resistance, Rebellion and Death. (J. O’Brien, Trans.). New York, NY: Alfred A. Knopf. (Original work published in 1960).

Dandicat, E. (2011). Create Dangerously: The Immigrant Artist at Work. New York, NY: Vintage Books.

Gramsci, A. (1971). Selections from the Prison Notebooks (Q. Hoare \& G. N. Smith, Trans.). New York: International Publishers Co.

hooks, b. (1994). Teaching to Transgress: Education as the Practice of Freedom. New York, NY: Routledge.

Horton, M., \& Freire, P. (1990). We Make the Road By Walking: Conversations on Education and Social Change. Temple University Press.

Lorde, A. (1984/2007). Sister Outsider: Essays and Speeches. New York, NY: Ten Speed Press.

Tuck, E. \& Yang, K. W. (2014). R-word: Refusing research. In D. Paris \& M. T. Winn (Eds.) Humanizing Research: Decolonizing Qualitative Inquiry with Youth and Communities (pp. 223248). Thousand Oaks, CA: Sage Publications. https://doi.org/10.4135/9781544329611.n12

Woodson, C. G. (1933). The mis-education of the Negro. Washington, D.C.: Associated Publishers. 


\section{Author Information}

Eric DeMeulenaere, Ph.D.

Associate Professor, Urban Schooling, Department of Education

Jacob Hiatt Center for Urban Education

Clark University

Worcester, MA 01610-1477

Telephone: 508.421.3750

Email: edemeulenaere@clarku.edu

Dr. DeMeulenaere earned his M.A. (1999) and Ph.D. (2003) in the Social and Cultural Studies Program at the University of California at Berkeley's Graduate School of Education. He taught middle and high school for eight years, and co-founded and led an innovative high school in East Oakland focused upon social justice. 